UDC 622.235.01

\title{
穿孔内の発破に関する研究*
}

正会員大䆶 敬 男**

\section{Study on Blasting in Boreholes}

Takao ŌKUBO

Only little study has been made in the past on blasting in boreholes and naturally, there are still many aspects of the phenomena caused at the time of blasting which need clarification. Using a detonating speed meter and an oscillograph adjusted to firing time and firing condition in boreholes, the writer has measured the detonating speed of cartridges of varying diameters as well as the degree of deformation of a copper rod attached to each of these explosives and thereby obtained data which will assist in assuming the conditions of detonation in boreholes. As a secondary experiment, the extent of propagation in detonation has also been measured.

\section{1. 緒}

穿孔内発破についての研究は従来から少なく爆轟時の 諸現象は解明されていないものが多い。筆者はメテガン グ法を応用した爆速計およびブラウン管オシログラフを 用いて, 穿孔内に撤登破時と条件を合せ, 各種薬径 の棒状装薬の穿孔内の爆速招よび穿孔内の薬包添付し た銅棒の変形量を測定して呀孔内の爆霸状態推定の 1 資 料をえたので報告する。な拈付属試験として穿孔内の殉 爆度を実測したので付記する。

\section{2. 爆 速 測 定}

いずれの測定装置に扣いでる穿孔内の薬包に直角に $0.35 \mathrm{~mm} \phi$ のエナメル被覆銅線を通して測点とし, 爆覈 によつてエナメル線を切断させその切断時閒を測定して 爆速を算出するものである。な怙雷管はすべて装薬の孔 底端に插入乙た。

\section{$2 \cdot 1$ 測 定 装 置}

$2 \cdot 1 \cdot 1$ 爆速計について：爆速測定の 1 方法としてメ テガング法があるがこの装置の内煤の代りにフィルム， レンズを用いて当所で爆速測定装置（爆速計）を製作し た。概略は第 1 目に示す。フィルムに映つた火花スポッ トの問隔, 薬包上の測点間隔, ドラムの回転数等から炎 速を換算する。精度は約 $5 \%$ である。

2・1・2 ブラウン管オシログラフについて：装置の概 略は第 2 圀に示す。精度は約 4\%である。ブラウン管は 東芝製 $120 \mathrm{~mm}$ ST-100/B 型である。

* 昭和 33 年 7月 24 日受理

** 日本鉱業株式会社河山鉱業所採鉱課
2.1·3 シンクロスコープについて：装置の概略は第 3 困に示す。シンクロスコープは岩崎通信機製 SS 1254 型である。精度は約 $3 \%$ である。

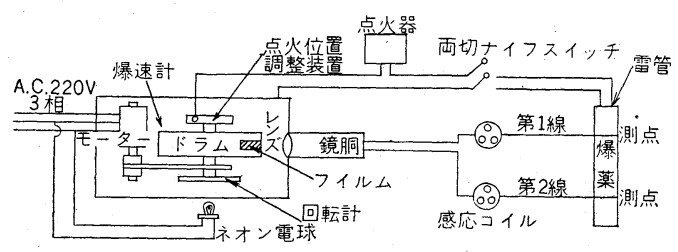

第 1 図

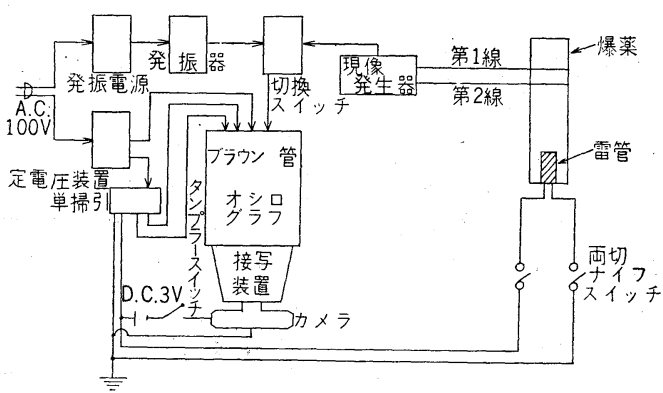

第 2 図

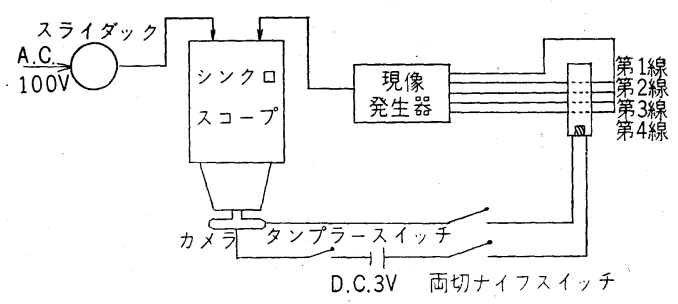

第 3 図 

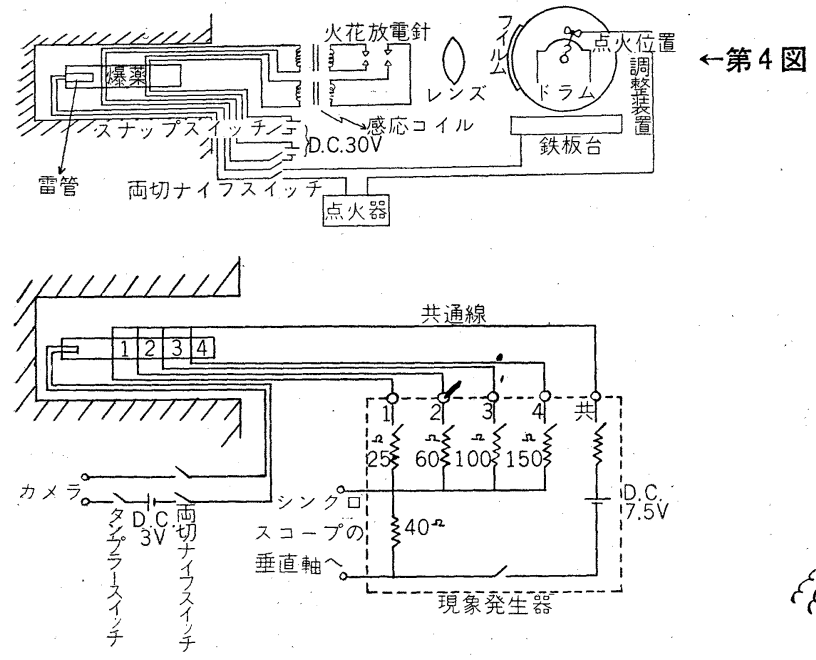

第 6 図

\section{$2 \cdot 2$ 測 定 方 法}

$2 \cdot 2 \cdot 1$ 爆速計の場合：呀孔内の測定回路図は第 4 四 北示す。エナメル線は切断後不定期接触を行いその都度 火花スポットがフィルムに映る可能性があるので 1 測点 につき 2 本とした。

$2 \cdot 2 \cdot 2$ ブラウン管オシログラフの場合：この場合は 第 5 困に示す。これも同様な理由によつてェナメル線を

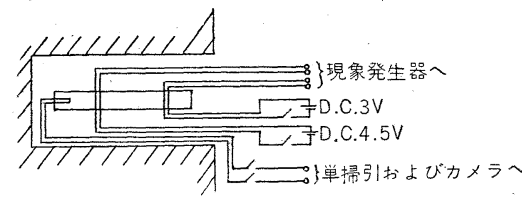

第 5 図

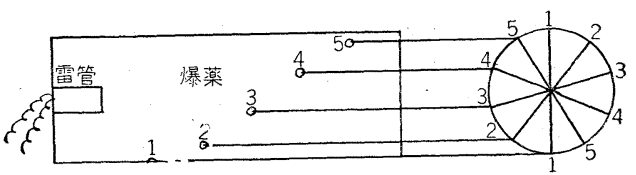

第 7 図

1 測点について2本にしてある。

$2 \cdot 2 \cdot 3$ シンクロスコープの場合：この場合は第 6 㘡 に示す。エナィルの片線を共通線として孔中を通るエナ メル線の本数を少なくし，なるべく多くの測点間の爆速 を実測出来る上うにした。また爆䨰後の不定期接触を防 ぐために第 7 四に示すように測線の方向を放射状にし て，各測線相互が薬包側面で重ならないようにした。

第 1 表

\begin{tabular}{|c|c|c|c|c|c|c|c|c|c|c|c|c|c|c|c|c|c|c|c|c|c|c|c|c|c|c|}
\hline \multirow[b]{2}{*}{ 薬 } & \multicolumn{9}{|c|}{ 測 } & \multicolumn{2}{|c|}{ 点 } & \multicolumn{3}{|c|}{ 位 } & \multicolumn{3}{|l|}{ 置 } & \multicolumn{9}{|c|}{$(\mathrm{cm})$} \\
\hline & $\begin{array}{l}0 \\
2 \\
5\end{array}$ & $\begin{array}{c}0 \\
\lambda_{1} \\
10\end{array}$ & $\begin{array}{c}5 \\
? \\
10\end{array}$ & $\begin{array}{c}10 \\
2 \\
15\end{array}$ & $\left|\begin{array}{c}10 \\
2 \\
20\end{array}\right|$ & $\begin{array}{c}15 \\
2 \\
20\end{array}$ & $\begin{array}{c}20 \\
2 \\
25\end{array}$ & $\begin{array}{c}20 \\
2 \\
30\end{array}$ & $\begin{array}{c}25 \\
2 \\
30\end{array}$ & $\begin{array}{c}30 \\
2 \\
40\end{array}$ & $\begin{array}{c}40 \\
? \\
50\end{array}$ & $\begin{array}{c}50 \\
? \\
60\end{array}$ & $\begin{array}{c}9 \\
2 \\
116.5\end{array}$ & $\left|\begin{array}{c}60 \\
2 \\
70\end{array}\right|$ & $\begin{array}{c}70 \\
2 \\
80\end{array}$ & $\begin{array}{c}28.5 \\
i \\
128.5\end{array}$ & $\mid \begin{array}{c}80 \\
l \\
90\end{array}$ & $\begin{array}{c}90 \\
z \\
100\end{array}$ & $\left|\begin{array}{c}100 \\
2 \\
110\end{array}\right|$ & $\left|\begin{array}{c}100 \\
2 \\
200\end{array}\right|$ & \begin{tabular}{c|c}
150 & 1 \\
2 & \\
160 & 2
\end{tabular} & $\left|\begin{array}{c}190 \\
2 \\
200\end{array}\right|$ & $\left|\begin{array}{c}200 \\
2 \\
210\end{array}\right|$ & $\left|\begin{array}{c}145 \\
? \\
295\end{array}\right|$ & $\left|\begin{array}{c}250 \\
2 \\
260\end{array}\right|$ & $\begin{array}{c}290 \\
2 \\
300\end{array}$ \\
\hline $\mathrm{LD}$ 桂 $20 \mathrm{~mm}$ & & & & & $\begin{array}{r}2580 \\
960\end{array} \mid$ & & $|1620|_{2}$ & 2970 & & $2040 \mid$ & 2040 & & 1980 & 2100 & & & 2030 & & $2720 \mid 2$ & 29102 & 2660 & & $\left|\begin{array}{l}2400 \\
2580\end{array}\right|$ & & $\left|\begin{array}{l}2840 \\
1930\end{array}\right|$ & \\
\hline $\mathbf{L D}$ 桂 $25 \mathrm{~mm}$ & & 2880 & & & 3130 & & & 3150 & & $|3190|$ & 3670 & & & & & & 2820 & & 2900 & & 3050 & & $3420 \mid$ & & 30603 & 3250 \\
\hline LD桂 $28 \mathrm{~mm}$ & \begin{tabular}{|l|} 
\\
3090 \\
2770 \\
2450 \\
3180
\end{tabular} & $\begin{array}{c}(5 \sim 15) \\
3080\end{array}$ & 3090 & & 3470 & \begin{tabular}{|l|}
2760 \\
3020 \\
3310 \\
2810
\end{tabular} & $\begin{array}{l}36003 \\
35703 \\
3520 \\
2900\end{array}$ & 3320 & & $\begin{array}{l}3200 \\
3230\end{array}$ & $\begin{array}{r}36503 \\
3 \\
3\end{array}$ & \begin{tabular}{|}
3450 \\
3000 \\
3140
\end{tabular} \mid & & & & 3410 & 3450 & 3300 & & 3280 & & & 3530 & & & \\
\hline LD桂 $32 \mathrm{~mm}$ & & & & 3230 & & & & 3790 & & $\mid \begin{array}{l}3320 \\
3260\end{array}$ & 3510 & \begin{tabular}{|}
3150 \\
3570 \\
3680
\end{tabular} & & & & & & & & $\left|\begin{array}{l}3460 \\
3440\end{array}\right|$ & & & $\left|\begin{array}{l}3410 \\
3350\end{array}\right|$ & & & \\
\hline LD桂 $40 \mathrm{~mm}$ & & & & & & & & & & & & & & & & & & & & $3840 \mid$ & & & & & & \\
\hline LD桂 $50 \mathrm{~mm}$ & & & & & 3800 & & & & & & & & & & & & & & 4030 & 3490 & & 3210 & & 51803 & $\mid 3970$ & \\
\hline 桐 $20 \mathrm{~mm}$ & & & & & & & & & & 1840 & $\left.2040\right|^{2}$ & 2030 & & & 2030 & & 1960 & & & $2500 \mid$ & & & & & & \\
\hline 桐 $25 \mathrm{~mm}$ & & & & & 3340 & & & & & 3110 & 3600 & & & $4640 \mid$ & & & & & & $4710 \mid$ & & & 5200 & & & \\
\hline 桐 $28 \mathrm{~mm}$ & & & & & $\begin{array}{l}1990 \\
2990\end{array}$ & & & 3820 & & & & & & & & & & & & 5910 & & & & 5180 & & \\
\hline 桐 $32 \mathrm{~mm}$ & $\begin{array}{l}2640 \\
3950 \\
3450 \\
2690 \\
\end{array}$ & $\begin{array}{l}4590 \\
3280 \\
4720\end{array}$ & 3020 & 5170 & $\begin{array}{l}35404 \\
44204\end{array}$ & & 572048 & 1880 & $\begin{array}{c}25 \sim 40) \\
4890\end{array}$ & 5720 & & 5800 & & & & & & & & 6460 & & & & 5210 & & \\
\hline 桐 $40 \mathrm{~mm}$ & & & & & & & & & & & & & & & & & & & & 6470 & & & & & & \\
\hline 桐 $50 \mathrm{~mm}$ & & & & & 6270 & & & & & & & & & & & & & & & 6260 & & & & & & \\
\hline
\end{tabular}




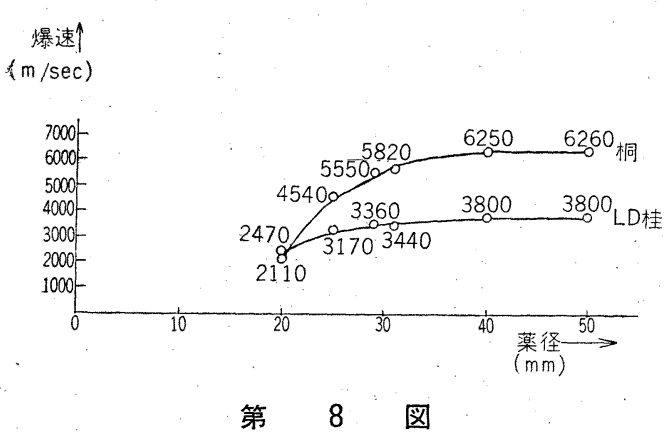

$2 \cdot 3$ 使 用 爆 薬

使用した薬種は桐ダイナマイト (NG $36 \%$, 比重 1.4) 揢よび L. D. 桂ダイナマイト（NG 8\%, 比重 0.7) の 2種類，薬径はそれぞれ 20，25，28，32，40，50mm の 5 種類である。また雷管は DSD 1 段を用い，ビットは $36,50,65 \mathrm{~mm} \phi$ のものを用いた。

\section{$2 \cdot 4$ 測 定 結 果}

測定結果は第 1 表に示す。

\section{$2 \cdot 5$ 測定結果に対する考察}

第 1 表から薬長一爆速の関係汇扣汀定常爆速域到達 距離は LD 桂の場合には雷管から $20 \sim 30 \mathrm{~cm}$, 桐の場合 には 40〜 $50 \mathrm{~cm}$ の所になる。つぎに各種の薬径について , ○定常爆速值を第 1 表から求めて見ると第 8 図の通りで 岁る。れから薬径一爆速の関係に和ける定常爆速到達 は桐, LD桂ともに薬径 32 40mm の間で, 定常爆速值 は桐では $6300 \mathrm{~m} / \mathrm{sec}, \mathrm{LD}$ 桂では $3800 \mathrm{~m} / \mathrm{sec}$ のように推 定される。また桐は LD桂に比べて薬径の減少に伴う爆 速值の減少速度が大きい。桐 $32 \mathrm{~mm} \phi$ と $28 \mathrm{~mm} \phi$ は定常 爆速值より一段低い爆速值を示すが桐 $25 \mathrm{~mm} \phi, 20 \mathrm{~mm} \phi$ の爆速值と比べると爆速值に大差のない 1 つのグループ と考えてもよいと思われる。LD 桂 $32 \mathrm{~mm} \phi$ と $28 \mathrm{~mm} \phi$ の

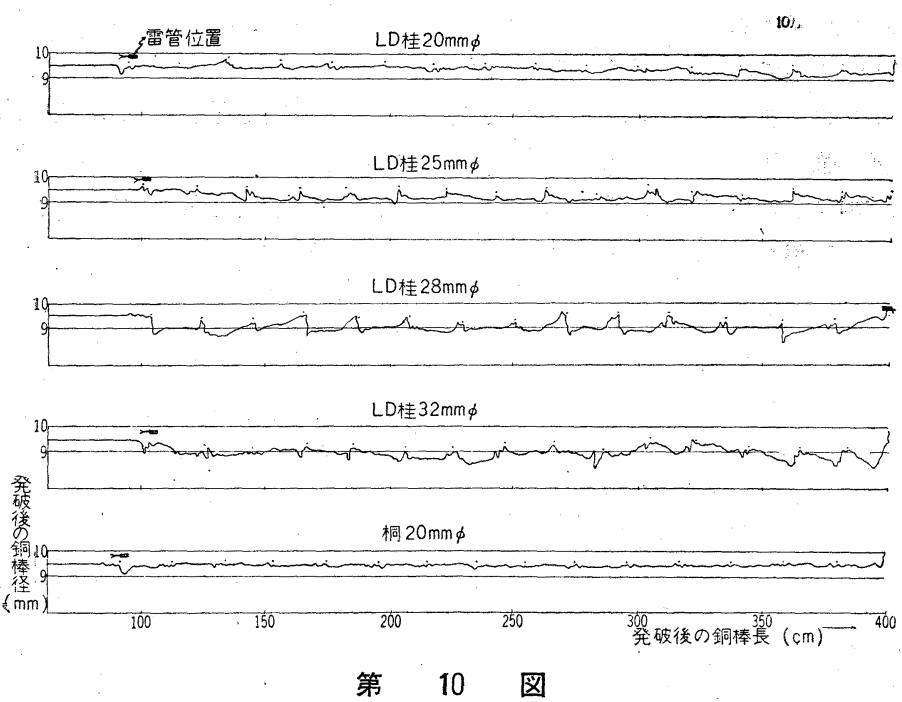

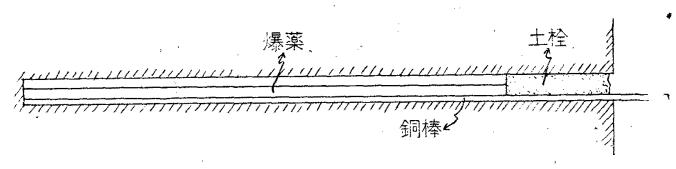

第 9 図

爆速值はほとんと同じと考它て上く，定常爆速值との差

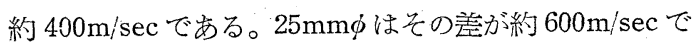
あるが $20 \mathrm{~mm} \phi$ の爆速值と比べると，32，28，25mm $\phi$ の 3 者は爆速值が大体等しい1つのグループのように推 定される。桐とLD桂とでは桐の方が爆速值が大きいの は当然であるが， $20 \mathrm{~mm} \phi$ になると反效に LD 桂の方が やや大きい爆速值を示している。

\section{3. 銅棒添付による爆轟状態の推定}

\section{$3 \cdot 1$ 測定装置および方法}

骁孔内の棒状装薬に銅棒を添付して薬包の爆轟による 銅棒の变形状態を観察して穿孔内の爆䡣状態を推定する .もので, 装置の概略は第9 図に示す。薬長 $3 \mathrm{~m}$ の爆薬に 直径 $9.5 \mathrm{~mm}$, 長さ $4 \mathrm{~m}$ の焼鈍銅棒を密着させてボアホ 一ルに装填し雷管を前管または尼管として起爆させ，爆 霸後变形を受けた銅棒の直径を測定した。爆薬ば桐ダイ ナマイト $20 \mathrm{~mm} \phi ，$ および LD 桂ダイナマイト $20 ， 25$, $28,32 \mathrm{~mm} \phi$ である。雷管は導火線付 6 号雷管，.ビット は $36,42 \mathrm{~mm} \phi$ を用いた。

\section{$3 \cdot 2$ 測 定 結 果}

測定結果は第10図执よび第 2 表に示す。雷管の付近で は爆力がまだ強くないので銅棒の径は爆䩗以前とあまり 変化がないが，爆曘が薬包に沿つて進さにつれて直径の 減少量が多くなり定常爆速域侄到達するまでこの状態が 続き，到達後屚平な大体同一の直径となる。な和薬包の 境では爆力が落らるために銅棒表面に節が出来る。爆力 が強いほど節は明膫となる。薬包の 位置は前後の節の位置で示される。

第 2 表

\begin{tabular}{|c|c|c|c|}
\hline 薬 & 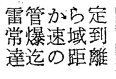 & \multicolumn{2}{|c|}{$\begin{array}{l}\text { 定常爆速域到 } \\
\text { 㒓後銅棒の } \\
\text { 平均直 径 }\end{array}$} \\
\hline LD桂20前管 I & $40 \mathrm{~cm}$ & $9.3 \mathrm{r}$ & $\mathrm{n} \sim 9.4 \mathrm{~mm}$ \\
\hline II II & 20 & 9.2 & $\sim 9.4$ \\
\hline LD桂 25 前管 I & 40 & 9.0 & \\
\hline II II & 10 & 9.0 & \\
\hline LD桂28前管 I & 30 & 8.4 & $\sim 8.6$ \\
\hline II II & 40 & 9.0 & \\
\hline I & 10 & 8.5 & $\sim 9.0$ \\
\hline LD桂28尻管 I & 10 & 9.0 & \\
\hline II II & 15 & 8.8 & $\sim 9.0$ \\
\hline II III & 不明 & 9.0 & \\
\hline $\mathrm{LD}$ 桂32 前管 I & 10 & 8.8 & $\sim 9.0$ \\
\hline II II & 10 & 8.5 & $\sim 9.0$ \\
\hline 桐 20 前 管 I & 40 & 9.4 & \\
\hline II II & 不明 & 9.4 & \\
\hline
\end{tabular}




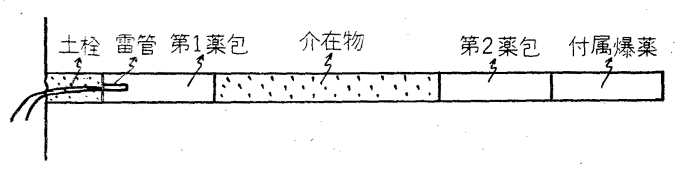

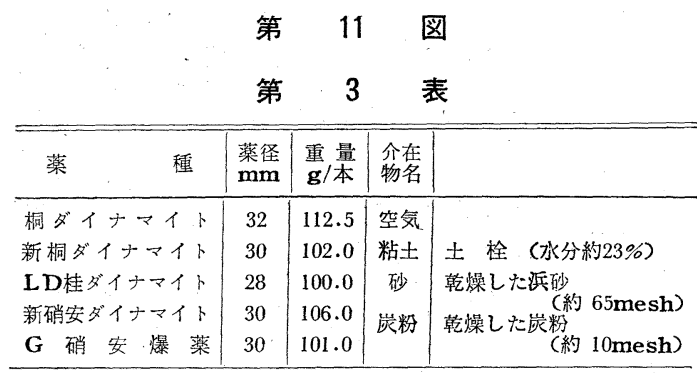

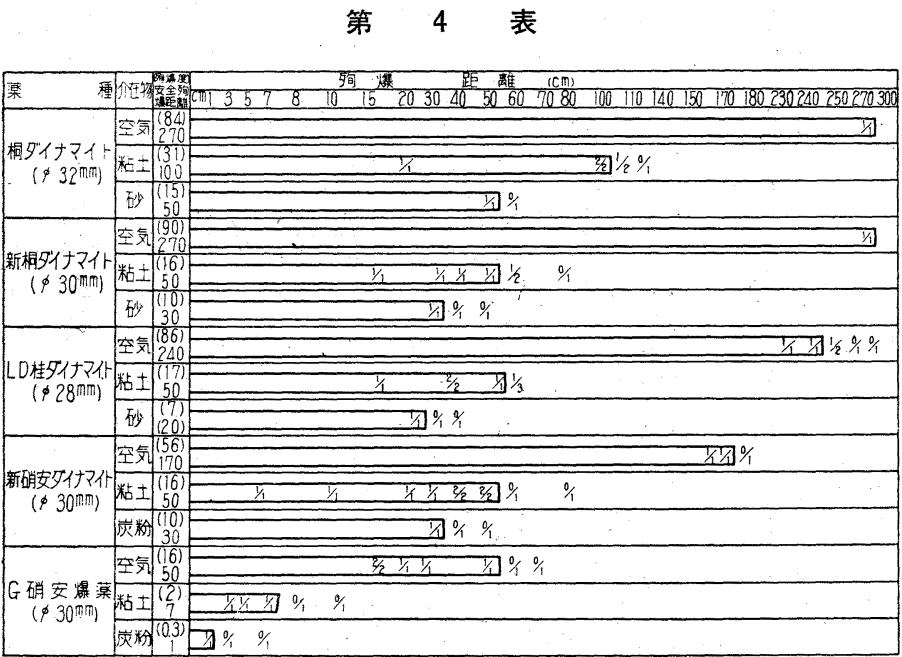

\section{$3 \cdot 3$ 測定結果に対する考察}

爆力は爆速が定常爆速に到達するまでは增大する過程 にあり到達後一定の強さになると思われるが，測定結果 からその位置はLD䅅に打いては 10〜 $40 \mathrm{~cm}$ の範囲にめ り, 薬径が増加するに従い $40 \sim 10 \mathrm{~cm}$ に縮まつて来て, より急速瀑力が一定の強さに達するようである。また 爆力そのものの強さも薬径が大きくなるに従い強くなつ てくるようである。これは LD 桂の薬径か増加するに従 つて銅棒の径も9.4 8.5mm 減少して来ている事から
推定出来る。そしてLD 桂 $28 \mathrm{~mm} \phi$ と $32 \mathrm{~mm} \phi$ の爆力の 強さは銅棒の变形量から見て大体同等の様である。

\section{4. 穿孔內の殉爆}

\section{$4 \cdot 1$ 測 定 方 法}

密閉中の殉爆に関しては鋼管を使用して実験例がある が，呀孔内の㱛爆については実験資料が少ないので，と りあ劣ず数種の爆薬について第 1 薬包と第 2 薬包との間 の介在物を種々变えて殉爆距離を和のおのの場合につい て求めた。第11図に測定方法を示す。第 2 薬包の後部に は薬包を 1 本追加して第 2 薬包の完爆状態を見る 1 手段 とした。使用した爆薬特よび介在物は第 3 表の通りであ る。また使用ビットは $36 \mathrm{~mm}$ ，雷管は 6 号雷管である。

\section{$4 \cdot 2$ 測 定 結 果}

測定結果を第 4 表に示す。なお表中の 分数は分母を試験回数, 分子をその時の 殉爆回数として表わす。また口 殉爆距離でこれ以内では第 2 薬包は爆発 する。第 4 表からつぎのことが推定出来 る。

介在物が空気の場合, 桐, 新桐 $270 \mathrm{~cm}$, $\mathrm{LD}$ 桂 $240 \mathrm{~cm}$, 硝ダイ $170 \mathrm{~cm}$, 硝爆 $50 \mathrm{~cm}$ の極めて大さい殉爆距離を示す。介在物 が空気以外の場合にはニトログリセリン を含有する爆薬では比較的大さい殉爆距 離を示すが，ニトログリセリンの少ない 硝爆にあつて介在物の影響が大きいので 殉爆距離は粘土で $7 \mathrm{~cm}$, 孷粉で $1 \mathrm{~cm}$ の ようにきわめて短かい。

\section{5. 結語}

本試験は測定方法に不備な点もありまた測定回数も少 ないので確定的な結論を出すまでには至つていない。今 後多くの実験が必要である。な打試験に際して御指導を いただいた現杤木鉱業所辛島鈜務課長に対し，また試験: 方法, 試験装置について御教示御援助をいただいた旭化 成延岡工場ダイナマイト部福山試験課長に対し深甚なる 感謝の意を表する次第である。 